\title{
APRESENTAÇÃO - CICLO DE DEBATES
}

\section{CICLO DE DEBATES INOVA MUNDO E A UTILIDADE SOCIAL DA PRODUÇÃO CIENTÍFICA EM ADMINISTRAÇÃO | RESENHAS ACOMPANHADAS POR NOTAS DE ENSINO}

A ciência passou a se desenvolver exponencialmente a partir do momento em que os EUA atribuíram ao conhecimento o mérito de terem ganho a Segunda Guerra Mundial. Do mesmo modo, no âmbito das organizações, "A gestão científica ganhou um impulso extraordinário a partir da atribuição do êxito dos EUA na Segunda Guerra Mundial à boa gestão em grandes corporações." (FARIA, 2011, p. 1165). Pode-se, ainda, argumentar que, durante a Guerra Fria, a gestão científica se disseminou para diversos outros países, entre eles o Brasil, "com o intuito de proteger o 'mundo livre' da ameaça comunista." (ALCADIPANI; BERTERO, 2012, p. 289).

Desde então, o campo científico da Administração cresceu com vigor no Brasil sob a égide da CAPES, cujo sistema de avaliação é para muitos pesquisadores o determinante principal do que se convencionou chamar de produtivismo acadêmico, que está centrado "na quantidade pura e simples de produções [...] em detrimento da qualidade científica ou da relevância social do que é publicado.” (GODOI; XAVIER, 2012, p. 456).

Para Alcadipani (2011, p. 1175), “O resultado é o que assistimos ano após ano [...]: artigos fracos, discussões rasas, falta de inovação conceitual, argumentos pouco rigorosos, artigos metodologicamente pífios [...] inúteis e inconsistentes."

Por conseguinte, hoje, a maioria dos pesquisadores brasileiros atua distante das organizações, não fazendo avançar a teoria sobre fenômenos locais e a reflexão sobre as práticas administrativas e seu aperfeiçoamento.

No entanto,

O País está longe de ser bem administrado, basta observar a má administração de recursos, a má qualidade dos serviços e a má gestão de projetos, que acarretam imenso prejuízo [...] Contribuir para uma melhoria da prática administrativa é missão importante da área. (BERTERO et al., 2013, p. 17).

Ademais, em tempos de crise, a falha do país em investir na geração de conhecimento próprio e em acessar e adaptar à sua realidade o conhecimento gerado em outros países se agrava ainda mais, condenando sua economia, sua indústria e seus cidadãos a um futuro de dependência, à mercê do colonialismo tecnológico.

A questão sobre o que (ainda resta a) fazer permanece sem resposta. É nesse contexto de fomento à utilidade social da produção científica que o Inova Mundo, uma agência nacional de notícias relacionadas ao mundo dos negócios, propõe-se a atuar no âmbito do jornalismo científico, apresentando, em linguagem simples e positiva, o que a Ciência tem a dizer ao setor produtivo e ao público em geral.

Esta seção inaugura, desse modo, um Ciclo de Debates constituído por três resenhas acompanhadas de notas de ensino a serem sistematicamente publicadas nos canais multimídia do Inova Mundo e na Revista Gestão em Análise, resultante da parceria que consolida o compartilhamento do conhecimento em sua essência e gestão.

\section{Raphael Campos*}

\section{Editor-científico do Inova Mundo}

\author{
Arnaldo Coelho $\mid$ Laodicéia Weersma \\ Editores - ReGeA
}


* $\quad<$ http://inovamundo.com.br>; https://www.facebook. com/redeinovamundo $>$;

$<$ https://www.instagram.com/inovamundo/?hl=pt-br>; <https://www.youtube.com/channel/UCCZLMcr7_Z8DvlmhYos8GBw $>$.

\section{REFERÊNCIAS}

ALCADIPANI, R. Resistir ao produtivismo: uma ode à perturbação acadêmica. Cadernos EBAPE. BR, Rio de Janeiro, v. 9, n. 4, p. 11741178, dez. 2011.

ALCADIPANI, R.; BERTERO, C. O. Guerra Fria e ensino do management no Brasil: o caso da FGV-EAESP. RAE-Revista de Administração de Empresas, São Paulo, v. 52, n. 3, p. 284-299, maio/jun. 2012.

BERTERO, C. O. et al. Produção científica brasileira em administração na década de 2000. RAE-Revista de Administração de Empresas, São Paulo, v. 53, n. 1, p. 12-20, jan./fev. 2013.

FARIA, A. Repensando produtivismo em gestão no (e a partir do) Brasil. Cadernos EBAPE. BR, Rio de Janeiro, v. 9, n. 4, p. 1164-1173, dez. 2011.

GODOI, C. K.; XAVIER, W. G. O produtivismo e suas anomalias. Cadernos EBAPE. BR, Rio de Janeiro, v. 10, n. 2, p. 456-465, jun. 2012.

\section{CYCLE OF DEBATES INNOVA WORLD AND THE SOCIAL UTILITY OF SCIENTIFIC PRODUCTION IN ADMINISTRATION | RESULTS ACCOMPANIED BY TEACHING NOTES}

Science began to develop exponentially from the moment that the United States gave the knowledge the merit of having won the Second World War. Similarly, within organizations, "Scientific management has gained an extraordinary boost from the attribution of US success in World War II to good management in large corporations." (FARIA, 2011, p. 1165). It can also be argued that, during the Cold War, scientific management spread to several other countries, including Brazil, "with the aim of protecting the 'free world' from the communist threat." (ALCADIPANI; BERTERO, 2012, p. 289 ).

Since then, the scientific field of Administration has grown with vigor in Brazil under the aegis of CAPES, whose evaluation system is for many researchers the main determinant of what is known as academic productivism, which is centered "on the pure and simple quantity of productions $[\ldots]$ to the detriment of the scientific quality or the social relevance of what is published." (GODOI; XAVIER, 2012, p. 456).

According to Alcadipani (2011, p. 1175), "The result is what we see year after year [...]: weak articles, shallow discussions, lack of conceptual innovation, little rigorous arguments, methodologically perfunctory articles [...] useless and inconsistent."

Therefore, today, most Brazilian researchers operate far from the organizations, failing to advance the theory about local phenomena and the reflection on administrative practices and their improvement.

However,

The country is far from being well managed, it is enough to observe the mismanagement of resources, the poor quality of the services and the poor management of projects, that cause immense damage [...] To contribute to an improvement of the administrative practice is the most important mission of the area. (BERTERO et al., 2013, p. 17).

Moreover, in times of crisis, the country's failure to invest in the generation of own knowledge and to access and adapt to its reality the knowledge generated in other countries is further aggravated, condemning its economy, its industry and its citizens to a future of dependence, at the mercy of technological colonialism.

The question of what (still remains to be done) remains unanswered. It is in this context of fostering the social usefulness of scientific production that Inova Mundo, a national news agency rela- 
ted to the world of business, proposes to act within the scope of scientific journalism, presenting, in simple and positive language, what Science has to say to the productive sector and the general public.

This section opens a Debate Cycle consisting of three reviews accompanied by teaching notes to be systematically published in Inova Mundo's multimedia channels and in the magazine Gestão em Análise, resulting from the partnership that consolidates the sharing of knowledge in its essence and management.

\section{Raphael Campos*}

\section{Scientific editor of Inova Mundo}

\section{Arnaldo Coelho | Laodicéia Weersma \\ Editors - ReGeA}

* $\quad<$ http://inovamundo.com.br>; https://www.facebook. com/redeinovamundo $>$;

$<$ https:/www.instagram.com/inovamundo/?hl=pt-br>; <https://www.youtube.com/channel/UCCZLMcr7 Z8DvlmhYos8GBw>.

\section{REFERÊNCIAS}

ALCADIPANI, R. Resistir ao produtivismo: uma ode à perturbação acadêmica. Cadernos EBAPE. BR, Rio de Janeiro, v. 9, n. 4, p. 11741178, dez. 2011.

ALCADIPANI, R.; BERTERO, C. O. Guerra Fria e ensino do management no Brasil: o caso da FGV-EAESP. RAE-Revista de Administração de Empresas, São Paulo, v. 52, n. 3, p. 284-299, maio/jun. 2012.

BERTERO, C. O. et al. Produção científica brasileira em administração na década de 2000. RAE-Revista de Administração de Empresas, São Paulo, v. 53, n. 1, p. 12-20, jan./fev. 2013.

FARIA, A. Repensando produtivismo em gestão no (e a partir do) Brasil. Cadernos EBAPE. BR, Rio de Janeiro, v. 9, n. 4, p. 1164-1173, dez. 2011.

GODOI, C. K.; XAVIER, W. G. O produtivismo e suas anomalias. Cadernos EBAPE. BR, Rio de Janeiro, v. 10, n. 2, p. 456-465, jun. 2012.

\section{CICLO DE DEBATES INOVA MUNDO Y LA UTILIDAD SOCIAL DE LA PRODUCCIÓN CIENTÍFICA EN ADMINISTRACIÓN | RESEÑAS ACOMPAÑADAS POR NOTAS DE ENSEÑANZA}

La ciencia pasó a desarrollarse exponencialmente a partir del momento en que Estados Unidos atribuyó al conocimiento el mérito de haber ganado la Segunda Guerra Mundial. De la misma manera, en el ámbito de las organizaciones, "La gestión científica ganó un impulso extraordinario a partir de la atribución del éxito de Estados Unidos en la Segunda Guerra Mundial a la buena gestión en grandes corporaciones" (FARIA, 2011, p. 1165). Se puede argumentar que durante la Guerra Fría la gestión científica se ha diseminado para otros países, entre ellos Brasil, "con el fin de proteger el 'mundo libre' de la amenaza comunista" (ALCADIPANI; BERTERO, 2012, p. 289).

Desde entonces, el campo científico de la Administración creció con vigor en Brasil bajo la égida de la CAPES, cuyo sistema de evaluación es para muchos investigadores el determinante principal de lo que se ha convenido llamar de productivismo académico, que está centrado "en la cantidad pura y simples de producciones [...] en detrimento de la calidad científica o de la relevancia social de lo que es publicado" (GODOI; XAVIER, 2012, p. 456).

Para Alcadipani (2011, p. 1175), "El resultado es lo que asistimos año tras año [...]: artículos débiles, discusiones poco profundas, falta de innovación conceptual, argumentos poco rigurosos, artículos metodológicamente insignificantes $[. .$.$] inútiles e inconsistentes".$

Por consiguiente, hoy, la mayoría de los investigadores brasileños actúan lejos de las organizaciones, no haciendo avanzar la teoría sobre fenómenos locales y la reflexión sobre las prácticas administrativas y su perfeccionamiento.

Sin embargo,

El país está lejos de ser bien administrado, basta observar la mala adminis- 
tración de recursos, la mala calidad de los servicios y la mala gestión de proyectos, que acarrean un enorme perjuicio [...] Contribuir a una mejora de la práctica administrativa es una misión importante del área. (BERTERO et al., 2013, p. 17).

Además, en tiempos de crisis, la falla del país en invertir en la generación de conocimiento propio y en acceder y adaptar a su realidad el conocimiento generado en otros países se agrava aún más, condenando su economía, su industria y sus ciudadanos a un futuro de dependencia, a merced del colonialismo tecnológico.

La cuestión sobre lo que (todavía queda) hacer permanece sin respuesta. Es en este contexto de fomento a la utilidad social de la producción científica que el Inova Mundo, una agencia nacional de noticias relacionadas al mundo de los negocios, se propone actuar en el ámbito del periodismo científico, presentando, en lenguaje simple y positivo, lo que la Ciencia tiene que decir al sector productivo y al público en general.

Esta sección inaugura de este modo un Ciclo de Debates constituido por tres reseñas acompañadas de notas de enseñanza a ser sistemáticamente publicadas en los canales multimedia de Inova Mundo y en la Revista Gestão em Análise, resultante de la asociación que consolida el compartir del conocimiento en su esencia y gestión.

\section{Raphael Campos*}

\section{Editor-científico del Inova Mundo}

\section{Arnaldo Coelho $\mid$ Laodicéia Weersma}

Editores - ReGeA

* $\quad<$ http://inovamundo.com.br>; https://www.facebook. com/redeinovamundo $>$;

$<$ https://www.instagram.com/inovamundo/?hl=pt-br>; <https://www.youtube.com/channel/UCCZLMcr7 Z8DvlmhYos8GBw>.

\section{REFERÊNCIAS}

ALCADIPANI, R. Resistir ao produtivismo: uma ode à perturbação acadêmica. Cadernos
EBAPE. BR, Rio de Janeiro, v. 9, n. 4, p. 11741178, dez. 2011.

ALCADIPANI, R.; BERTERO, C. O. Guerra Fria e ensino do management no Brasil: o caso da FGV-EAESP. RAE-Revista de Administração de Empresas, São Paulo, v. 52, n. 3, p. 284-299, maio/jun. 2012.

BERTERO, C. O. et al. Produção científica brasileira em administração na década de 2000. RAE-Revista de Administração de Empresas, São Paulo, v. 53, n. 1, p. 12-20, jan./fev. 2013.

FARIA, A. Repensando produtivismo em gestão no (e a partir do) Brasil. Cadernos EBAPE. BR, Rio de Janeiro, v. 9, n. 4, p. 1164-1173, dez. 2011.

GODOI, C. K.; XAVIER, W. G. O produtivismo e suas anomalias. Cadernos EBAPE. BR, Rio de Janeiro, v. 10, n. 2, p. 456-465, jun. 2012. 